\author{
Velimir Ćirović \\ Research Assistan \\ University of Belgrade \\ Faculty of Mechanical Engineering \\ Dušan Smiljanić \\ PhD Student \\ University of Belgrade \\ Faculty of Mechanical Engineering
}

Dragan Aleksendrić

Associate Professor University of Belgrade Faculty of Mechanical Engineering

\section{Neuro-Genetic Optimization of Disc Brake Performance at Elevated Temperatures}

The basic problem of automotive brakes operation is the decreasing of their performance at elevated temperatures in the contact of friction pair (brake disc and brake pad). Increasing of the brake interface temperature often causes decreasing of braking torque during a braking cycle. In order to provide the stable level of braking torque during a braking cycle, the neural network based optimization model of the disc brake performance has been developed. The dynamic neural networks have been employed for modelling of complex synergy of tribological phenomena that affects the final disc brake performance at elevated temperatures. The dynamic optimization neural network model of disc brake performance at elevated temperatures has been developed using recurrent neural networks. It predicts the braking torque versus the dynamic change of the brake actuation pressure, sliding speed and the brake interface temperature in a braking cycle. Genetic algorithms were integrated with the neural network model for optimization of the brake actuation pressure in order to obtain the desired level of braking torque. This hybrid, neuro-genetic model was successfully used in optimization of the brake hydraulic pressure level needed to achieve the maximum and stable brake performance during a braking cycle.

Keywords: neural networks, genetic algorithms, optimization, disc brakes, brake performance.

\section{INTRODUCTION}

Non-linear systems or systems whose behaviour depends on their current state are just some of the many systems that need modelling and optimization [1]. In that sense, automotive braking system represents the most important system of motor vehicles that has these characteristics. According to [2,3], the main purpose of automotive braking systems is to control braking torques applied to the wheels, allowing a vehicle to decelerate in an optimum manner while maintaining directional stability during maneuvers. In particular, the demands imposed on a braking system, over a wide range of operating conditions, are complex. The brakes are supposed to provide high and stable values of braking torque over different brake operating conditions determined by synergistic influence of actuation pressure and/or sliding speed and/or brake interface temperature. The brake interface temperature has a strong influence on the final brake performance since the high temperature levels could cause deterioration of braking torque, and in turn prolonged braking distance. The brake performance and its temperature sensitivity is an issue that should be better control in terms of providing stabilization and maximization of the brake

Received: December 2012, Accepted: January 2014

Correspondence to: Velimir Simovic

Faculty of Mechanical Engineering,

Kraljice Marije 16, 11120 Belgrade 35, Serbia

E-mail:vsimovic@mas.bg.ac.rs

doi:10.5937/fmet1402142C

(C) Faculty of Mechanical Engineering, Belgrade. All rights reserved performance for the current braking regimes.

Regarding modern automotive brakes, as well as maximum speeds of today's vehicles, the extreme demands have been imposed on the friction couple and its tribological performance [4-7]. One of the most important braking phenomena is different sensitivity of braking torque against change of actuation pressure, sliding speed and brake interface temperature. Besides, the properties of the friction material play often a crucial role in driver's perception of braking performance, especially at elevated brake interface temperatures [8-10]. Widespread opinion relates to drivers, who expect relatively constant level of brake performance at various braking regimes. Since this is very important when braking is performed at elevated brake temperatures, stable braking torque level in such braking situations during a braking cycle is a very important issue. The braking torque should remain on the stable level, during a braking cycle, and maximized versus change of the speed, pressure and the brake interface temperature. Due to often and high fluctuation of the brake performance, especially when braking torque loss occurs at elevated brake temperatures, stability of the brake performance is not provided. Such brake performance is reflected to driver as confusing feedback of vehicle dynamics and the braking system performance. That is the main reason why optimization and dynamic control of the brakes performance in a braking cycle should be provided. It means that dynamically changed functional relationship between the brake actuation pressure, vehicle speed and the 
brake interface temperature, from the one side, and the braking torque, from the other, should be established. That functional relationship could be further used for dynamic control and optimization of the disc brake performance versus different brake operation conditions and driver demands.

Due to very complex and highly non-linear phenomena involved into the braking process, an analytical model of dynamic change of the brake performance versus its operation conditions changes are almost impossible to be obtained [11-13]. This significantly complicates the process of control of automotive brakes performance $[14,15]$. That is why, intelligent methods should be introduced in modelling, control, and optimization of highly non-linear processes [16-18] such as a braking process. An implementation of artificial intelligence should provide development of intelligent methods that incorporate adaptation and learning [19]. In this paper, an intelligent approach to optimization of the brake performance of a passenger car was proposed based on synergy of artificial neural networks and genetic algorithms. Investigation presented in this paper contributes to the efforts in the direction of intelligent braking. Thus, the hybrid neurogenetic optimization model has been developed that is able to provide dynamic control and optimization of braking torque value by adjusting of the brake actuation pressure according to the influence of the brake interface temperatrure and sliding speed. Recurrent neural networks have been used for dynamic modelling of synergetic influences of the current values of the disc brake actuation pressure, speed, and brake interface temperature. Furthermore, genetic algorithms have used this model for optimizing and adjusting the disc brake actuation pressure on the level which provides stable and maximum value of braking torque. The optimization process has been done according to the brake pedal travel i.e. the brake actuation pressure selected by a driver. It could be considered as a new intelligent way for development of the advance brake assistance system.

\section{EXPERIMENT CONDUCTING}

The modelling process of automotive brake performance is very demanding and difficult due to dynamic behavior of the braking process. The situation is additionally complicated if the braking is performed at elevated temperature in the contact of brake friction pair. That is why, developing of a dynamic model able to learn and generalize complex tribological behavior of the disc brake in dynamic operating conditions is required to provide preconditions for control of the brake performance. Considering their functional properties, layer-recurrent neural networks, as a class of dynamic neural networks, were employed to achieve this goal. Developing of a dynamic neural model of disc brake performance requires training of dynamic neural networks with data organized as time series. Thus, data related to brake actuation pressure, sliding speed, brake interface temperature, and braking torque, were collected by testing of the brake using a single-end fullscale inertial dynamometer, see Fig. 1. According to fade performance test, appropriate testing methodology has been established, where the tested disc brake was applied with actuation pressure of 40 bar while initial values of sliding speed were $90 \mathrm{~km} / \mathrm{h}$. The brake interface temperature was between $100-290^{\circ} \mathrm{C}$. The braking torque was selected to represent output performance of the disc brake.

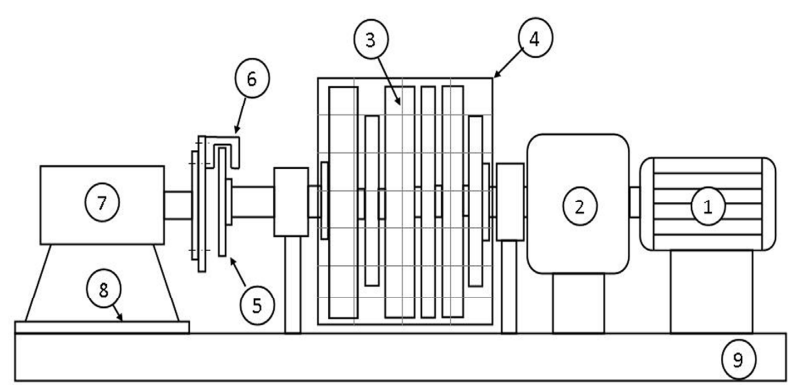

Figure 1. Single-end full-scale inertial dynamometer

Regarding Fig. 1, components of the dynamometer are: 1 - the electromotor, 2 - reductor, 3 - set of flywheels for providing of different inertial masses, 4 protective cage for flywheels (provide safety), 5 - firmly jointed brake disc, 6 - brake caliper (fixed part), 7 system for measurement of braking torque, 8 - axial slider for distance setting, and 9 - common foundation of the inertial dynamometer. The tested disc brake was designed for mounting on the front axle of passenger car with static load of $730 \mathrm{~kg}$. Regarding the fade performance test, the total number of braking cycles that have been done was 30. Brake actuation pressure, sliding speed, brake interface temperature, and braking torque, whose functional dependence was modeled by recurrent neural networks, were measured by appropriate pressure, speed, temperature and torque sensors. All data related to these parameters were collected with sampling rate of $40 \mathrm{~Hz}$. Brake interface temperature has been measured by a thermocouple sensor, with probe that was mounted in the hole (drilled in the brake pad). An example of change of all measured parameters during a randomly-chosen braking cycle is shown in Fig. 2. Due to memory of dynamic neural networks they can be trained to learn sequential or time-varying patterns, and that is why changes of disc brake performance (represented by braking torque) versus influence of braking conditions (defined by brake applied pressure, sliding speed and the brake interface temperature) must be considered as a function of time. The complexity of change of braking torque during a braking cycle (see Fig. 2), indicates that development of dynamic model capable to establish the functional relationship between parameters with such complex change, and particularly in dynamic operating conditions, is not an easy task. In order to be further used to control the disc brake performance through a neuro-genetic optimization of the brake actuation pressure, a dynamic neural model should be able to learn the nature of change of these measured parameters. Moreover, it should be able to store the knowledge about the braking process and exploit capabilities of recurrent neural networks to use the history of previous changes of input/output parameters. 

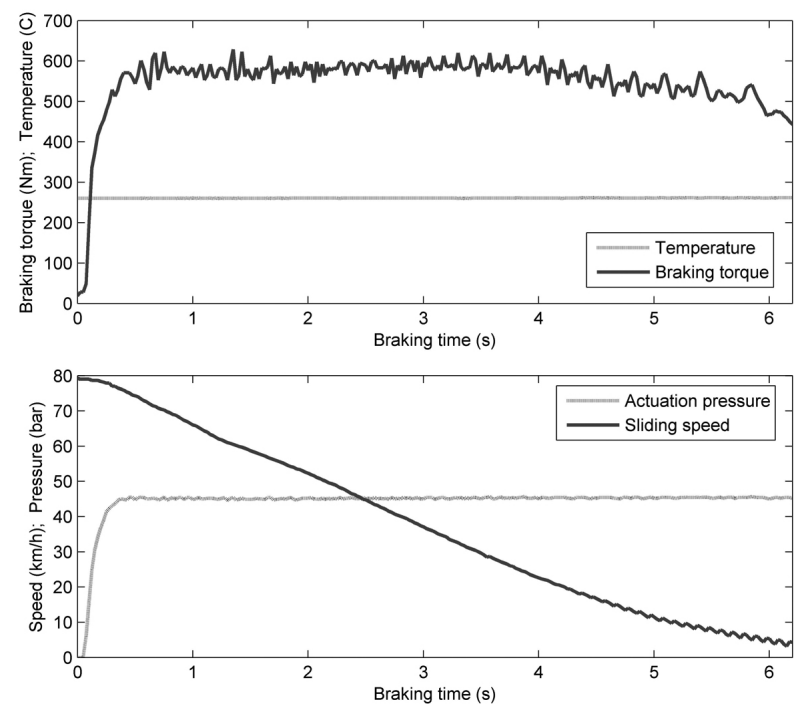

Figure 2. An example - Measured the inputs/output parameters of a braking cycle

\section{RECURRENT NEURAL NETWORK MODELLING}

In neural network theory, dynamic neural networks are generally more powerful than static networks since they have memory that can remember the past values and states of the network [20]. The output of the dynamic network depends on the current input values as well as on the previous inputs, outputs or states of the network. This is the reason why the gradient must be computed in a more complex way compared to static neural networks. Mitigation is that dynamic neural networks can be trained using the same learning algorithms that are used for static networks. In general, dynamic neural networks can be feed-forward or feedback (recurrent) networks. Feedback or recurrent neural networks are built in such way that the outputs of some neurons are fed back to the same neurons or to neurons in the preceding layers. In this way, network outputs at a given instant reflect the current input as well as previous inputs and outputs that are gradually quenched. In this paper, the subcategory of dynamic neural networks, commonly known as the Layer-Recurrent network, has been employed for dynamic modelling of the disc brake performance. This type of recurrent neural networks is characterized by a feedback loop, with a single delay, around each layer of the network except for the last (output) layer. This means that the influence of previous braking torque values on its current value is represented through feedback connections after each of hidden layers, known as Layer delay states.

In this paper, 45 different layer-recurrent neural networks have been investigated against influence of three training algorithms: Resilient Backpropagation (RP), Levenberg-Marquardt (LM), and Bayesian Regularization (BR), respectively. The tansig activation function has been used between the input and the first hidden layer, as well as between the hidden layers. The purelin activation function has been used between the last hidden and the output layer. The total number of 30 braking cycles have been divided into training and test data sets ( 20 braking cycles for training, and 10 braking cycles for testing of the neural models). Among the total number of tested models, the dynamic model based on the layer-recurrent neural network architecture with one hidden layer that contains 8 neurons (see Fig. 3) showed the best prediction performance. This neural model was trained with Bayesian Regularization algorithm.

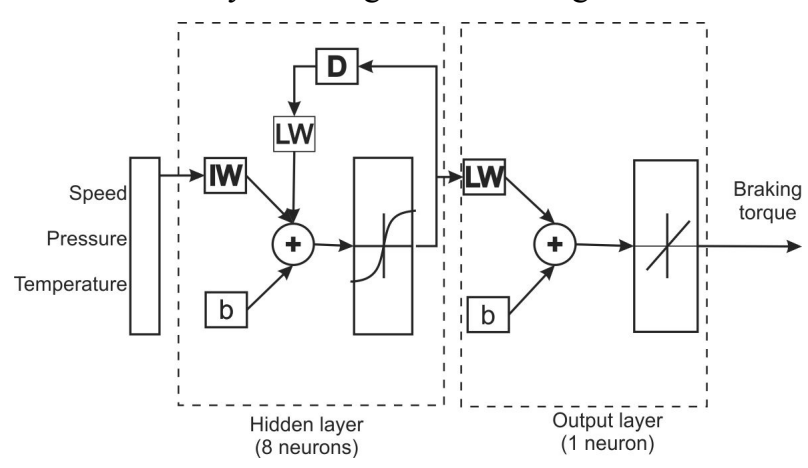

Figure 3. Dynamic neural model of disc brake operation based on Layer-Recurrent network

\section{GENETIC ALGORITHM OPTIMIZATION}

Genetic algorithms have been used in this paper to provide optimization capabilities of the developed dynamic model of disc brake performance. As one of the popular artificial intelligence methods, genetic algorithms represent search algorithms based on the mechanics of natural selection and natural genetics [21]. Until now, they have been used for many optimization tasks, particularly combined with other techniques of artificial intelligence, as it is shown in $[22,23,24]$. The basic GA optimization cycle is shown in Fig. 4. As it can be seen, genetic algorithms start with initial population of random chosen individuals, called chromosomes, from the design space and search the input range effectively for required output variables by means of reproduction, crossover, and mutation $[25,26,27]$. In every evolutionary step, known as a generation, the individuals in the current population are evaluated according to some predefined quality criterion, referred to as fitness function, i.e. objective function [28]. This means that genetic algorithm repeatedly modifies a population of individual solutions.

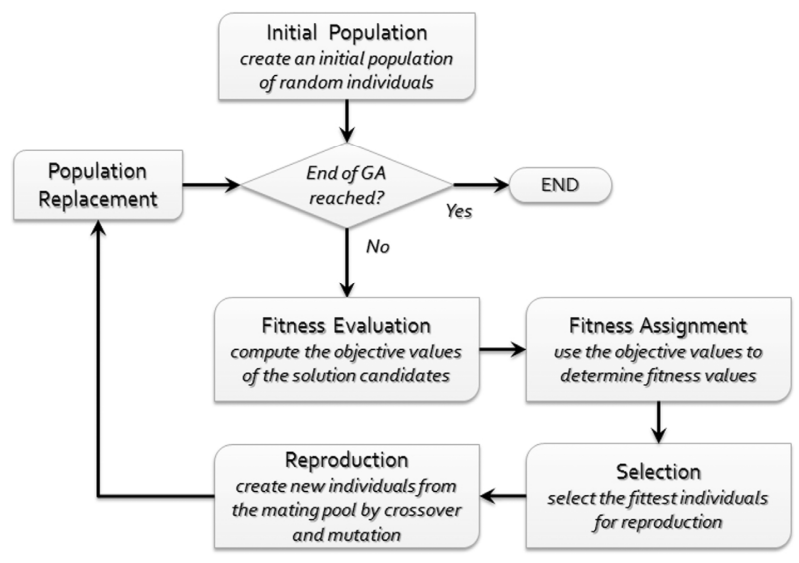

Figure 4. The basic cycle of genetic algorithms

There are three main types of rules which genetic algorithm uses at each step to create the next generation from the current population: (i) Selection - selecting of the individuals, called parents, that contribute to the 
population at the next generation, (ii) Crossover combining two parents in order to form children for the next generation, and (iii) Mutation - applying random changes to individual parents in order to form children. At each step, the genetic algorithm selects individuals at random from the current population to be parents and uses them to produce the children for the next generation. As the process continues over successive generations, the population "evolves" towards an optimal solution.

In this paper, genetic algorithms were used in combination with developed dynamic neural model in order to find the value of the brake actuation pressure, versus driver demands, for dynamic controlling of braking torque. An implementation of genetic algorithms was provided using Genetic Algorithm solver in the program package Matlab 7.11. Fig. 5 illustrates the flow chart of the hybrid ANN-GA optimization model developed for that purpose. This integrated approach to optimization could be summarized into five main steps: (1) The genetic algorithm generates an initial population of individuals for applied brake pressure; (2) After that, the fitness of each chromosome is evaluated. Also, a fitness value for each chromosome by the developed recurrent neural model is assigned; (3) Creating a population for the next generation by the genetic operations (selection, crossover and mutation) with the probabilities based on fitness of the each chromosome is following afterwards; (4) The genetic algorithm then sends the new child generation to recurrent neural model as new input parameter; (5) Finally, calculating of the fitness by developed recurrent neural model is performed. The last four steps are repeated until the terminating criterion has been met. Obviously, thus conceived optimization process exploits ability of genetic algorithm to optimize neural network inputs using the trained dynamic neural model as its fitness function. Regarding Fig. 5, fitness of each individual is calculated by dynamic neural model in the each evolutionary step. By simulating the neural model for dynamic changes of speed and temperature in a braking cycle, the brake actuation pressure was optimized also in a dynamic manner, taking into consideration dynamic changes of the real and target braking torque values, and such defined nonlinear constraints. These constraints for fitness function value were formed based on the simulation model and the target value of braking torque.

The constraint is defined as a difference between predicted and target braking torque values. Target braking torque was defined as a value which provides stable and/or maximum braking torque during a braking cycle. By performing a minimization of a difference between these real and target values of braking torque, genetic algorithm searches the optimal value of the brake actuation pressure during a braking cycle. The main goal is that the difference between real and target braking torque converges to zero during a series of successive generations of individuals. As the fitness function value, over successive generations, approaches towards the criteria being set, the brake actuation pressure converges to the optimal one.

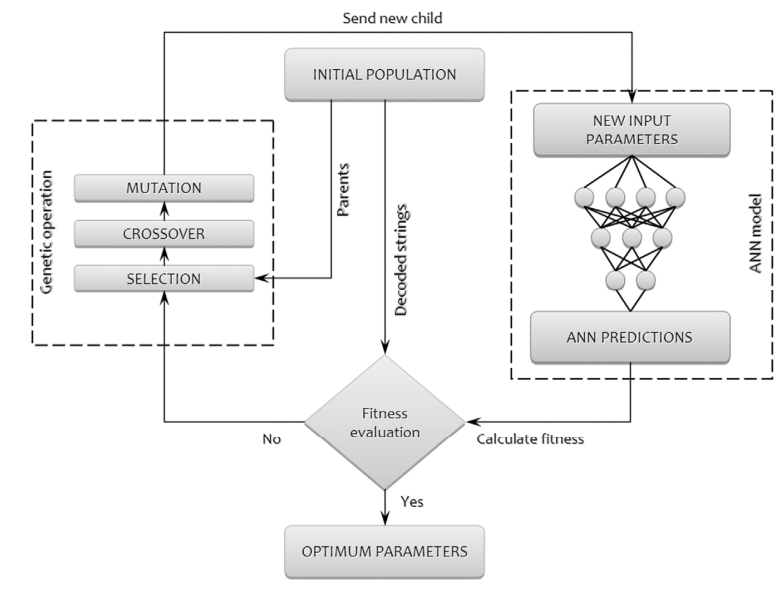

Figure 5. A hybrid neuro-genetic optimization model

\section{RESULTS AND DISCUSSION}

The diversity and substantial variations of the real braking torque versus synergistic influence of the brake actuation pressure, the sliding speed, and brake interface temperature should be better controlled in order to simultaneously provide stable and maximum braking performance. High temperature level at the contact of the friction couple and consequently changes of coefficient of the friction are main negative issues of the brake operation at elevated temperatures. As it is presented in the paper, we investigated possibilities to reduce these negative influences on the brake performance though the neuro-genetic optimization of the brake actuation pressure. The hybrid approach used in the paper could enable optimization of the brake performance against different setting of wanted, i.e. target brake performance. In that sense, two different ways for selection of wanted brake performance have been investigated. The first approach was to find the brake actuation pressure that provides the maximum performance of the brake during a braking cycle, according to the brake real tribological behaviour. The second approach was to optimize the brake applied pressure to provide not only the maximum performance of the brake but also to stabilize the braking torque. It is important because the first approach eliminate decreasing of braking torque with speed decreasing in a braking cycle at elevated temperatures, for example. That negative effect of the brake operation at elevated temperatures could be avoided or suppressed by adjusting, i.e. optimizing of the brake actuation pressure during a braking cycle.

The dynamic neural model's prediction of the braking torque has been verified through a comparison between the real and predicted braking torque. Figs. 6 and 7 show examples of this comparison for braking cycles where the brake interface temperature was $203^{\circ} \mathrm{C}$ and $285^{\circ} \mathrm{C}$, respectively. In both situations, sliding speed changes between $10-80 \mathrm{~km} / \mathrm{h}$, mean maximum value of the brake actuation pressure was between 40-50 bar, and the real braking torque changes between 350$550 \mathrm{Nm}$. As it can be seen, the real braking torque had intensive oscillations, particularly at the end of braking, at elevated temperatures (Fig. 7). The model recognized 
how all influencing factors (pressure, speed, and temperature) affecting the braking torque value during a braking cycle. Fig. 6 shows that generalization capabilities of the dynamic neural model were on the acceptable level. Regarding change of the predicted braking torque, it was able to deal with large fluctuations of the brake performance during a braking cycle.

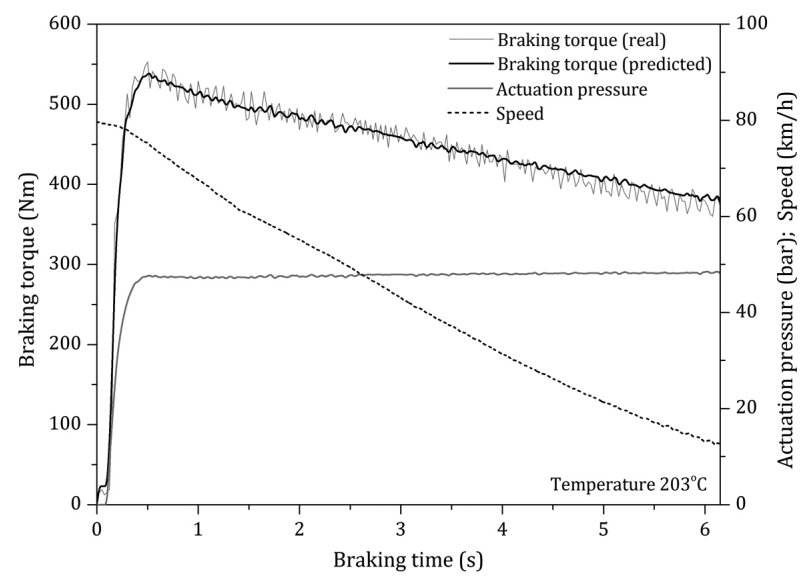

Figure 6. Braking torque prediction by the dynamic neural model (temperature $203^{\circ} \mathrm{C}$ )

The neural model's abilities have been further investigated by analyzing of the situation when the brake interface temperature was on higher level $\left(285^{\circ} \mathrm{C}\right)$, see Fig. 7. As it was shown in Fig. 6, the real braking torque constantly decreases for about $200 \mathrm{Nm}$ to the end of a braking cycle. Compared to the braking cycle showed in Fig. 6, oscillations of the real braking torque are more intensive at elevated temperatures (Fig. 7). It is evident from Fig. 7 that the dynamic neural model showed more sensitivity in the prediction of the real braking torque changes. This is particularly important because the dynamic model could be then used for fine-tuning of the disc brake performance versus change of speed, pressure, and brake interface temperature.

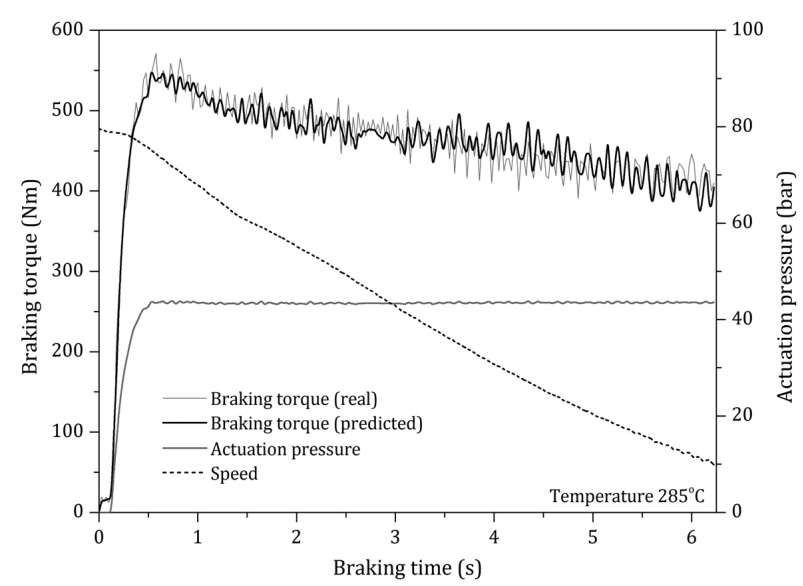

Figure 7. Braking torque prediction by the dynamic neural model (temperature $285^{\circ} \mathrm{C}$ )

Fig. 8 shows the optimization process of the brake actuation pressure versus the real actuation pressure selected by a driver. According to Fig. 8, the brake operation conditions, related to synergistic influence of pressure - speed - temperature in a braking cycle, caused variations of braking torque in the wide range. Mean maximum value of the real brake actuation pressure was 48 bar for the initial speed of $79 \mathrm{~km} / \mathrm{h}$ and the brake interface temperature of $155^{\circ} \mathrm{C}$. The minimum brake performance was obtained at the end of braking cycle. The maximum braking torque has been decreased from $580 \mathrm{Nm}$ to $450 \mathrm{Nm}$, see Fig. 8. Consequently, the brake can not obtain the same performance in a whole braking cycle. That is why, value of the braking torque at the end of braking should be corrected to obtain stable the brake performance regardless the vehicle speed and the brake interface temperatures. It is further important for providing an appropriate the brake pedal feel.

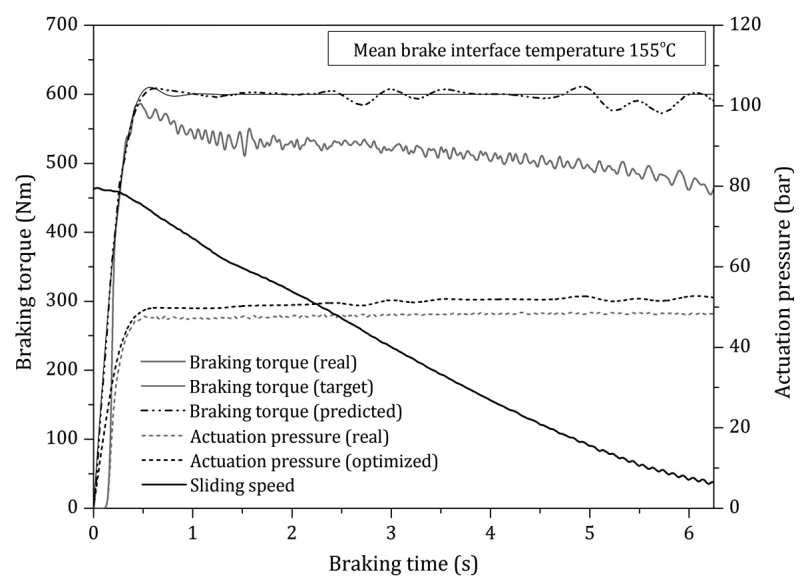

Figure 8. Optimization of the brake actuation pressure (temperature $155^{\circ} \mathrm{C}$ )

Stabilization and maximization of braking torque could be done in different ways. In this paper, proposed optimization process provides stable and at the same time maximized brake performance in accordance with the selected target braking torque value (see line target braking torque in Fig. 8). The brake actuation pressure was optimized in order to provide target braking torque versus the pressure selected by the driver and the real change of the braking torque. Since the proposed approach provides the dynamic adaptation of the brake performance in a braking cycle, the wanted brake performance could be differently defined.

Results of the optimization process are shown in Fig. 8. Line denoted as Actuation pressure (optimized) represents optimized change of the brake actuation pressure that should be used for the brake actuation in order to provide change of braking torque denoted as target braking torque. It is evident in Fig. 8 that, for the real brake actuation pressure of 48 bar, the brake should be activated with the higher pressure whose change was shown as optimized actuation pressure. It means that the mean maximum value of the brake actuation pressure should be increased to 54 bar. According to Fig. 8, the neuro - genetic optimization model, based on the dynamic neural model of the brake performance, was found the optimum change of the brake actuation pressure during a braking cycle which correcting the braking torque on the desired level (see predicted braking torque in Fig. 8). The braking torque change denoted as predicted represents a simulated change of braking torque by the dynamic neural model versus 
change of actuation pressure optimized by neuro-genetic approach.

In order to analyse the braking situation, when the vehicle braking is performed with higher the brake interface temperature in the contact of friction pair $\left(251^{\circ} \mathrm{C}\right)$, a braking cycle shown in Fig. 9 has been investigated. According to Fig. 9, the brake actuation pressure generated by the driver was 46 bar (real actuation pressure). The range of real braking torque variation, for initial speed of $78 \mathrm{~km} / \mathrm{h}$, was $200 \mathrm{Nm}$ in this case. This braking situation, i.e. deterioration of the brake performance should be avoided because it provokes longer braking distance and poor the brake pedal feel. Once again, the minimum braking torque was obtained near the end of braking cycle, and maximum braking torque was obtained for sliding speed of $76 \mathrm{~km} / \mathrm{h}$. Obviously, change of the real braking torque is more complex than in the previous case (see Fig. 8) when the brake interface temperature was on lower level. As it was explained in the previous case (temperature $155^{\circ} \mathrm{C}$ ), the brake actuation pressure has been optimized to provide stable and at the same time maximum the brake performance (see target braking torque in Fig. 9). Changes in the brake actuation pressure during a braking cycle could suppress or eliminate a difference in braking torque caused by the friction pair temperature sensitivity. Increasing of the brake actuation pressure to 62 bar at the start of braking, the brake responsiveness has been improved and braking torque change has been stabilized (Fig. 9, see line predicted braking torque). This pressure has been slightly increased to 73 bar during a braking cycle (see line optimized actuation pressure) in order to correct the brakes performance at the end of braking cycle in the sense of their maximization. Furthermore, braking time and braking distance will be shorted. According to Figs. 8 and 9 , the brake performance could be controlled by correcting, i.e. optimizing the brake pressure selected by the driver.

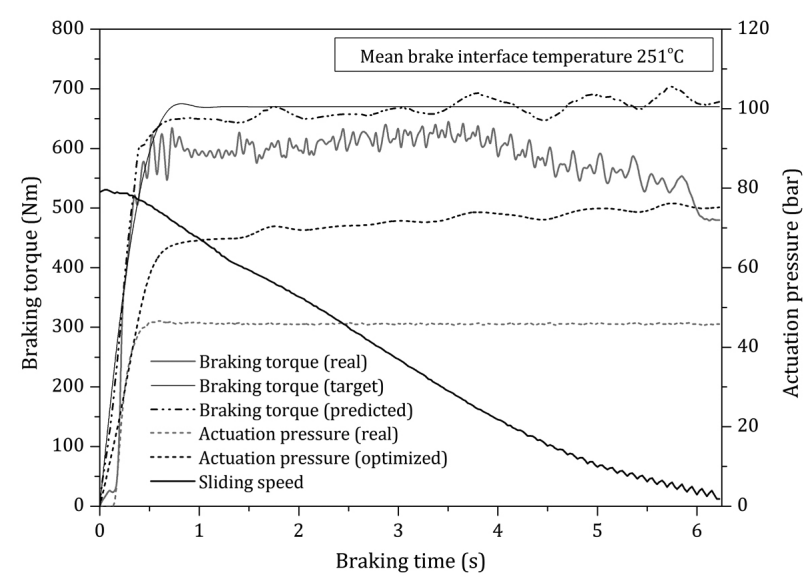

Figure 9. Optimization of the brake actuation pressure (temperature $251^{\circ} \mathrm{C}$ )

The situation is very similar in the case of braking with the brake interface temperature of $296^{\circ} \mathrm{C}$, see Fig. 10. In this common braking situation, it is particularly important to have a stable and maximum performance during a braking cycle. Using the neuro-genetic optimization of the brake actuation pressure, the pressure could not be only increased, as it is a case with traditional brake assistance system, but also the brake performance were better controlled during a braking cycle. According to Fig. 10, in order to correct the real brakes performance the neuro-genetic optimization model has been used for finding the brake actuation pressure (66 bar) bar at the start of braking, which providing not only the brake maximum performance but also stable performance during a braking cycle (see Fig. 10, lines optimized actuation pressure and predicted braking torque). It caused, see Fig. 10, significant increasing of braking torque in the last $3 \mathrm{sec}$ of a braking cycle. Regarding the line predicted braking torque in Fig. 10, its maximum value $(660 \mathrm{Nm})$ was obtained after $0.6 \mathrm{sec}$ from the start of braking.

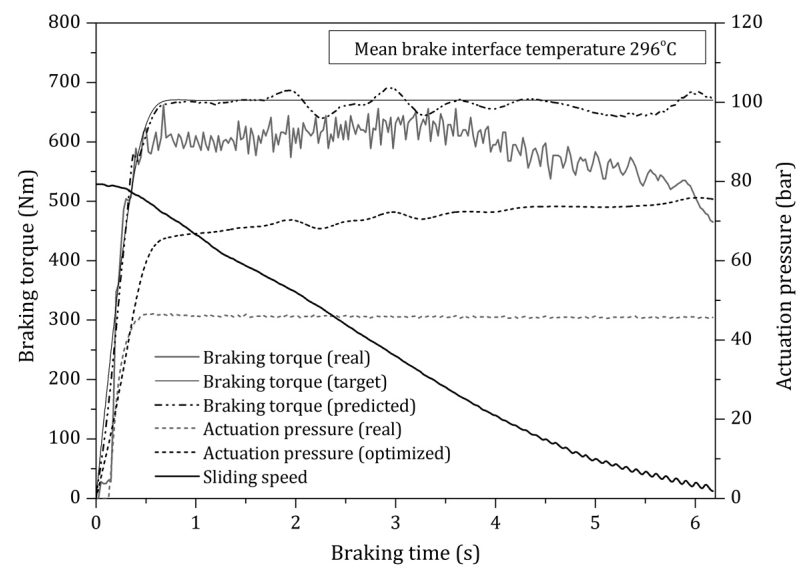

Figure 10. Optimization of brake actuation pressure (temperature $296^{\circ} \mathrm{C}$ )

\section{CONCLUSIONS}

In this paper, a neuro-genetic approach was used to investigate possibilities for optimization and improvement of the brake performance during a braking cycle. The neuro-genetic optimization model of the disc brake performance has been developed with main goal to correct the brake performance versus the influence of the pressure-speed changing during a braking at elevated temperatures. The model has shown inherent capabilities to recognize the influences of the pressure, the speed and the brake interface temperature on a dynamic change of braking torque. This model integrated with the genetic algorithms provided optimization of the brake actuation pressure in order to bring the brake performance on the wanted level. It was shown that maximum and stable the brake performance can be provided by dynamic adaptation of the brake actuation pressure against the negative effects of the brake interface temperature increasing.

\section{ACKNOWLEDGEMENT}

Authors gratefully acknowledge to Serbian Ministry of Education and Science for financial support of this research through the projects No. TR35045 and TR35030.

\section{REFERENCES}

[1] Blanco, A., Delgado, M. and Pegalajar, M.C.: A real-coded genetic algorithm for training recurrent 
neural networks, Neural Networks, Vol. 14, pp. 93105, 2001.

[2] Ozdalyan, B.: Development of a slip control antilock braking system model, International Journal of Automotive Technology, Vol. 9, pp. 71-80, 2008.

[3] Lee, K.M. et al.: Improved genetic algorithm for mixed-discrete-continuous design optimization problems, Engineering Optimization, Vol. 42, pp. 927-941, 2010.

[4] Ericsson, M.: Friction and Contact Phenomena of Disc Brakes Related to Squeal, Comprehensive summaries of Uppsala dissertation from Faculty of Science and Technology, Uppsala, 2000.

[5] Xiao, G., and Zhu, Z.: Friction materials development by using DOE/RSM and artificial neural network, Tribology International, Vol. 43, pp. 218-227, 2010.

[6] Talib, R.J., Muchtar, A. and Azhari, C.H.: Microstructural characteristics on the surface and subsurface of semimetallic automotive friction materials during braking process, Journal of Materials Processing Technology, Vol. 140, pp. 694-699, 2003.

[7] Rukiye, E. and Nurettin, Y.,: An experimental study of the effects of manufacturing parameters on the tribological properties of brake lining, Wear, Vol. 268, pp. 1524-1532, 2010.

[8] Aleksendrić, D. and Duboka, Č.: Fade performance prediction of automotive friction materials by means of artificial neural networks, Wear, Vol. 262, Issues 7-8, pp. 778-790, 2007.

[9] Aleksendrić, D., Duboka, Č., Ćirović, V.: Intelligent Control of disc brake operation, $26^{\text {th }}$ Annual Brake Colloquium 2008, SAE Paper 200801-2570, Texas, USA, 2008.

[10]Aleksendrić, D., Barton, D.C. and Vasić, B.: Prediction of brake friction materials recovery performance using artificial neural networks, Tribology International, Vol. 43, pp. 2092-2099, 2010.

[11] Aleksendrić, D. and Barton, D.C.: Neural network prediction of disc brake performance, Tribology International, Vol. 42, Issue 7, pp. 1074-1080, 2009.

[12] Aleksendrić, D., Jakovljević, Ž. and Ćirović, V.: Intelligent control of braking process, Expert Systems with Applications, Vol. 39/14, pp. 1175811765, 2012.

[13] Ćirović, V., Aleksendrić, D. and Mladenović, D.: Braking torque control using recurrent neural networks, Proceedings of the Institution of Mechanical Engineers, Part D: Journal of Automobile Engineering, Vol. 226, pp. 754-766, 2012.

[14] Aleksendrić, D. and Ćirović, V.: Dynamic control of disc brake performance, SAE 2012 Annual Brake Colloquium and Exhibition, SAE Paper 2012-01-1837, San Diego, USA, 2012.
[15]Ćirović, V. and Aleksendrić, D.: Dynamic modelling of disc brake contact phenomena, FME Transactions, Vol. 39, pp. 177-183, 2011.

[16] Ćirović, V. and Aleksendrić, D.: Development of neural network model of disc brake operation, FME Transactions, Vol. 38, pp. 29-38, 2010.

[17] Sinha, K., Krishnan, R., and Raghavendra, D. Multi-objective robust optimization for crashworthiness during side impact, International Journal of Vehicle Design, Vol. 43, pp. 116 - 135, 2007.

[18] Miljković, Z. and Aleksendrić, D.: Artificial Neural Networks - solved examples with theoretical background, Faculty of Mechanical Engineering University of Belgrade, 2009, (In Serbian), ISBN 978-86-7083-685-3.

[19] Masten, K.M.: Electronics: The intelligence and intelligent control, Annual Reviews, Vol. 22, pp. 111, 1998.

[20] Terzic, E., Nagarajah, C.R. and Alamgir, M.: Capacitive sensor-based fluid level measurement in a dynamic environment using neural network, Engineering Applications of Artificial Intelligence, Vol. 23, Issue 4, pp. 614-619, 2010.

[21] Weise, T.: Global Optimization Algorithms Theory and Application, Available from: http://www.it-weise.de/, 2009.

[22] Wu, M.H., Lin, W., and Duan, S.Y.: Developing a neural network and real genetic algorithm combined tool for an engine test bed, Proceedings of the Institution of Mechanical Engineers, Part D: Journal of Automobile Engineering, Vol. 220, pp. 1737-1753, 2006.

[23] Lee, K.M. et al.: Improved genetic algorithm for mixed-discrete-continuous design optimization problems, Engineering Optimization, Vol. 42, pp. 927-941, 2010.

[24] Manan, A. et al.: Optimization of aeroelastic composite structures using evolutionary algorithms, Engineering Optimization, Vol. 42, pp. 171-184, 2009.

[25] Mashinchi, M.R. and Selamat, A.: An improvement on genetic-based learning method for fuzzy artificial neural networks, Applied Soft Computing, Vol. 9, pp. 1208-1216, 2009.

[26] Ko, Y.D., Moon, P., Kim, C.E., Ham, M.H., Myoung, J.M. and Yun, I.: Modelling and optimization of the growth rate for $\mathrm{ZnO}$ thin films using neural networks and genetic algorithms, Expert Systems Application, Vol. 36, pp. 40614066, 2009.

[27] Srinivasu, D.S. and Babu, N.R.: A neuro-genetic approach for selection of process parameters in abrasive water jet cutting considering variation in diameter of focusing nozzle, Applied Soft Computing, Vol. 8, pp. 809-819, 2008.

[28] Kesgin, U.: Genetic algorithm and artificial neural network for engine optimization of efficiency and NOx emission, Fuel, Vol. 83, pp. 885-895, 2004. 


\section{НЕУРО-ГЕНЕТСКА ОПТИМИЗАЦИЈА \\ ПЕРФОРМАНСИ ДИСК КОЧНИЦЕ НА ПОВИШЕНИМ ТЕМПЕРАТУРАМА}

\section{Велимир Ћировић, Душан Смиљанић, Драган Алексендрић}

Основни проблем у раду кочница моторних возила је пад њихових перформанси на повишеним температурама у контакту фрикционог пара кочнице (кочног диска и диск плочице). Повећање температуре у контакту фрикционог пара кочнице често доводи до пада вредности момента кочења у току циклуса кочења, а самим тим и до смањења излазних перформанси кочнице. Да би се обезбедила стабилност момента кочења у току циклуса кочења, развијен је оптимизациони модел на бази динамичких вештачких неуронских мрежа. Развијени модел је искоришћен за моделирање сложених синергијских утицаја који доводе до појаве триболошких феномена који утичу на излазне перформансе диск кочнице. Динамички оптимизациони неуронски модел перформанси диск кочнице је развијен на бази рекурентних неуронских мрежа. Модел предвиђа динамичку промену момента кочења у зависности од тренутних вредности притиска активирања кочнице, брзине и темературе у контакту фрикционог пара у току циклуса кочења. Генетски алгоритми су интегрисани са неуронским динамичким моделом у циљу оптимизације притиска активирања кочнице који у току циклуса кочења треба да обезбеди жељену вредност момента кочења. Овакав хибридни, неуро-генетски, модел је показао могућност успешне оптимизације вредности хидрауличког притиска активирања кочнице, потребан да би се постигле стабилне и максимизиране излазне перформансе кочнице у току циклуса кочења. 